\title{
Light quality, 6-benzyladenine and number of subcultives for in vitro multiplication of hybrid clones of Corymbia
}

\author{
Qualidade de luz, 6-benziladenina e número de subcultivos para a \\ multiplicação in vitro de clones híbridos de Corymbia
}

\author{
Denys Matheus Santana Costa Souza ${ }^{1}$ (D), Aloisio Xavier² (), Natane Amaral Miranda ${ }^{3}$ (D), \\ Ricardo Gallo 4 (D), Wagner Campos Otoni ${ }^{5}$ (D) \\ ${ }^{1}$ Universidade Federal de Lavras - UFLA, Lavras, MG, Brasil \\ ${ }^{2}$ Universidade Federal de Viçosa - UFV, Viçosa, MG, Brasil \\ ${ }^{3}$ Universidade Federal Rural do Rio de Janeiro - UFRRJ, Seropédica, RJ, Brasil \\ ${ }^{4}$ Universidade Federal Rural de Pernambuco - UFRPE, Recife, PE, Brasil \\ ${ }^{5}$ Universidade Federal de Viçosa - UFV, Viçosa, MG, Brasil
}

How to cite: Souza, D. M. S. C., Xavier, A., Miranda, N. A., Gallo, R., \& Otoni, W. C. (2020). Light quality, 6benzyladenine and number of subcultives for in vitro multiplication of hybrid clones of Corymbia. Scientia Forestalis, 48(128), e3282. https://doi.org/10.18671/scifor.v48n128.03

\begin{abstract}
Micropropagation has been recommended in the search for alternatives for rejuvenation/reinvigoration of selected Corymbia clones, mainly to improve clonal seedling production. The objective of this work was to evaluate the effect of light quality, 6- benzyladenine (BA) concentrations and number of subcultures for in vitro multiplication of hybrid Corymbia clones (TC01, TC02, TC03 and CT01). Light qualities (white LEDs, red/blue LEDs, and fluorescent lamps), BA concentrations $\left(0.5,1.0,1.5\right.$, and $\left.2.0 \mathrm{mg} \mathrm{L}^{-1}\right)$ and number of subcultures were evaluated at 30 days after inoculation in JADS medium by length, number, vigor and oxidation of axillary shoots. Based on the results obtained, the use of $\mathrm{red} / \mathrm{blue}$ LEDs resulted in the best responses for the clones evaluated for in vitro multiplication. Regarding to BA, the most appropriate concentration of this growth regulator was $0.5 \mathrm{mg} \mathrm{L}^{-1}$ for TC01, TC02 and TC03 and $1.0 \mathrm{mg} \mathrm{L}^{-1}$ for СТ01, promoting better shoot development. The ninth subculture presented the best results compared to the clones analyzed for number of shoots per explant and vigor of axillary shoots.
\end{abstract}

Keywords: Micropropagation; Cytokine; Growth regulator; LEDs.

\section{Resumo}

A micropropagação tem sido recomendada quando se busca por alternativas para o rejuvenescimento/revigoramento de clones selecionados de Corymbia, visando à melhoria da produção de mudas clonais. O objetivo deste trabalho foi avaliar o efeito da qualidade de luz, da 6 - benziladenina (BA) e do número de subcultivos na multiplicação in vitro de clones híbridos de Corymbia (TC01, TC02, TC03 e CT01). As qualidades de luz (LEDs branco, LEDs vermelho/azul e Lâmpada fluorescente), as concentrações de 6 - benziladenina $\left(0,5 ; 1,0 ; 1,5\right.$ e 2,0 $\left.\mathrm{mg} \mathrm{L}^{-1}\right)$ e o número de subcultivos foram avaliados aos 30 dias após a inoculação em meio JADS, mediante o comprimento, o número, o vigor e a oxidação das brotações axilares. Com base nos resultados obtidos, o uso de LEDs vermelho/azul resultou nas melhores respostas para os clones avaliados na multiplicação in vitro. No que tange ao regulador de crescimento, a concentração mais adequada de BA foi de $0,5 \mathrm{mg} \mathrm{L}^{-1}$ para TC01, TC02 e TC03 e de 1,0 mg L-1 para o CT01, promovendo melhor desenvolvimento das brotações. Em relação ao número de subcultivos, o nono apresentou os melhores resultados diante dos clones analisados para as características de número de brotos por explante e vigor das brotações axilares.

Palavras-chave: Micropropagação; Citocinina; Regulador de crescimento; LEDs.

Financial support: None.

Conflict of interest: Nothing to declare.

Correspondig author: dmscsouza@gmail.com

Received: 12 February 2019.

Accepted: 16 October 2019.

Editor: Francides Gomes Silva Júnior.

(c) This is an Open Access article distributed under the terms of the Creative Commons Attribution License, which permits unrestricted use,

c) distribution, and reproduction in any medium, provided the original work is properly cited. 


\section{INTRODUCTION}

The expansion of forest plantations to non-traditional regions and the search for better seedling production have increased the use of species and hybrid combinations. Thus, the hybridization of Corymbia citriodora (Hook.) K.D. Hill \& L.A.S. Johnson with Corymbia torelliana (F. Muell.) K.D. Hill \& L.A.S Johnson has provided excellent results, both in wood quality and growth, in addition to better environmental adaptation (Assis, 2014; Trueman et al., 2018). Considering this fact, there has been an increase in research in Brazil on the micropropagation of Corymbia species and their hybrids (Brondani et al., 2018; Souza et al., 2018; Trueman et al., 2018).

In order to understand the limiting factors of the in vitro multiplication stage, the need for basic studies to promote the maximization of microcutting production is evident. Several technologies have been proposed in order to automate the micropropagation process, among them stand out; new diode-based lighting sources-LEDs; adequacy of growth regulators and rejuvenation/reinvigoration, according to the number of subcultures (Gupta \& Jatothu, 2013; Brondani et al., 2018; Batista et al., 2018).

Recent studies have reported how different levels of wavelength influence plant metabolism. According to Batista et al. (2018) blue (450 - $495 \mathrm{~nm})$ and red (620 - $750 \mathrm{~nm}$ ) light influence in vitro morphogenesis and plant growth and development. In addition to photosynthetic processes, light can act as an external signal for regulation in various morphogenic and physiological processes that influence the plant's architecture and phytochemicals level (Hsie et al., 2019; Faria et al., 2019).

A positive response to in vitro multiplication is due, among several factors, to the number of subcultures, aiming at rejuvenation/reinvigoration and an adequate balance of growth regulators; with 6-benzyladenine (BA) being of great relevance for the formation of shoots, proliferation of lateral buds and for overcoming the apical dominance exerted by auxins (ElShowk et al., 2013; Martínez-Estrada et al., 2017).

In view of the need to adapt the micropropagation to Corymbia torelliana $\times$ C. citriodora and Corymbia citriodora $\times$ C. torelliana clones, the present study aimed to evaluate the effect of light quality, BA and the number of subcultures in the in vitro multiplication phase.

\section{MATERIAL AND METHODS}

\section{Location of the study and experimental material}

The experiments were conducted at the Tissue Culture Laboratory II of the Institute of Biotechnology Applied to Agriculture (BIOAGRO), at the Federal University of Viçosa - UFV, in the municipality of Viçosa/MG. The material used to obtain the explants came from ministumps of three clones of Corymbia torelliana $\times$ C. citriodora (TC01, TC02 and TC03) and one of Corymbia citriodora $\times$ C. torelliana (CT01), from the company CMPC - Celulose Riograndense, located in the municipality of Guaíba/RS.

For the multiplication phase, the shoots produced in the in vitro establishment stage were prepared, isolating a standardized $0.5 \mathrm{~cm}$ of shoots and inoculated under aseptic conditions, in $150 \times 25 \mathrm{~mm}$ test tubes, containing $10 \mathrm{~mL}$ of culture. For all experiments, the JADS culture medium (Correia et al., 1995), added with $30 \mathrm{~g} \mathrm{~L}^{-1}$ of sucrose (Vetec $\left(\right.$ )), $100 \mathrm{mg} \mathrm{L}^{-1}$ of myoinositol (Sigma $\left.®\right)$, $800 \mathrm{mg} \mathrm{L}^{-1}$ PVP-30 (polyvinylpyrrolidone - Vetec $\left(\right.$ ), $0.5 \mathrm{mg} \mathrm{L}^{-1}$ of BA (6 - Benzyladenine - Sigma Co), $0.01 \mathrm{mg} \mathrm{L}^{-1}$ of NAA (naphthalenoacetic acid - Sigma®) and $6 \mathrm{~g} \mathrm{~L}^{-1}$ agar (Merck®). The culture medium was prepared with deionized water and the $\mathrm{pH}$ was adjusted to $5.8 \pm 0.05$ with $\mathrm{NaOH}(0.1$ $\mathrm{M})$ and/or $\mathrm{HCl}(0.1 \mathrm{M})$, before adding the agar and autoclaving. The autoclaving of the culture medium was carried out at a temperature of $121^{\circ} \mathrm{C}$ and a pressure of approximately $1 \mathrm{kgf} \mathrm{cm}^{-2}$, for 20 minutes. The experiments were maintained in a growth room at $25 \pm 2{ }^{\circ} \mathrm{C}$ for a 16 -hour photoperiod and irradiance of $40 \mu \mathrm{mol} \mathrm{m}^{-2} \mathrm{~s}^{-1}$ (quantified by radiometer, LI-COR®, LI-250A Light Meter). 


\section{Light quality}

In order to compare the quality of light, the experiment was arranged in a completely randomized design in a $4 \times 3$ factorial arrangement, with four Corymbia hybrid clones (TC01, TC02, TC03 and CT01) and three light sources: Fluorescent lamp - F/L (HO Sylvania T12, $110 \mathrm{~W}$, São Paulo, Brazil), White LED Lamp - W/L (SMD 100, 18 W, Vilux®, Vitória, ES, Brazil) and Red/Blue LED Lamp - R/B (LabPARLL-HR / DB-480, 11.6 W, LabLumens ${ }^{\circledR}$, Carapicuíba, SP, Brazil), with four replications, composed of plots with ten explants.

For the analysis of the variations of absolute irradiance $\left(\mu \mathrm{W} \mathrm{cm} \mathrm{cm}^{-1}\right)$ and the wavelength $(\mathrm{nm})$ of light emitted by the different types of lamps, the spectroradiometer (Ocean Optics Spectra-Suite) was used. From the data survey, the different light spectra were plotted in graphs (Figure 1).

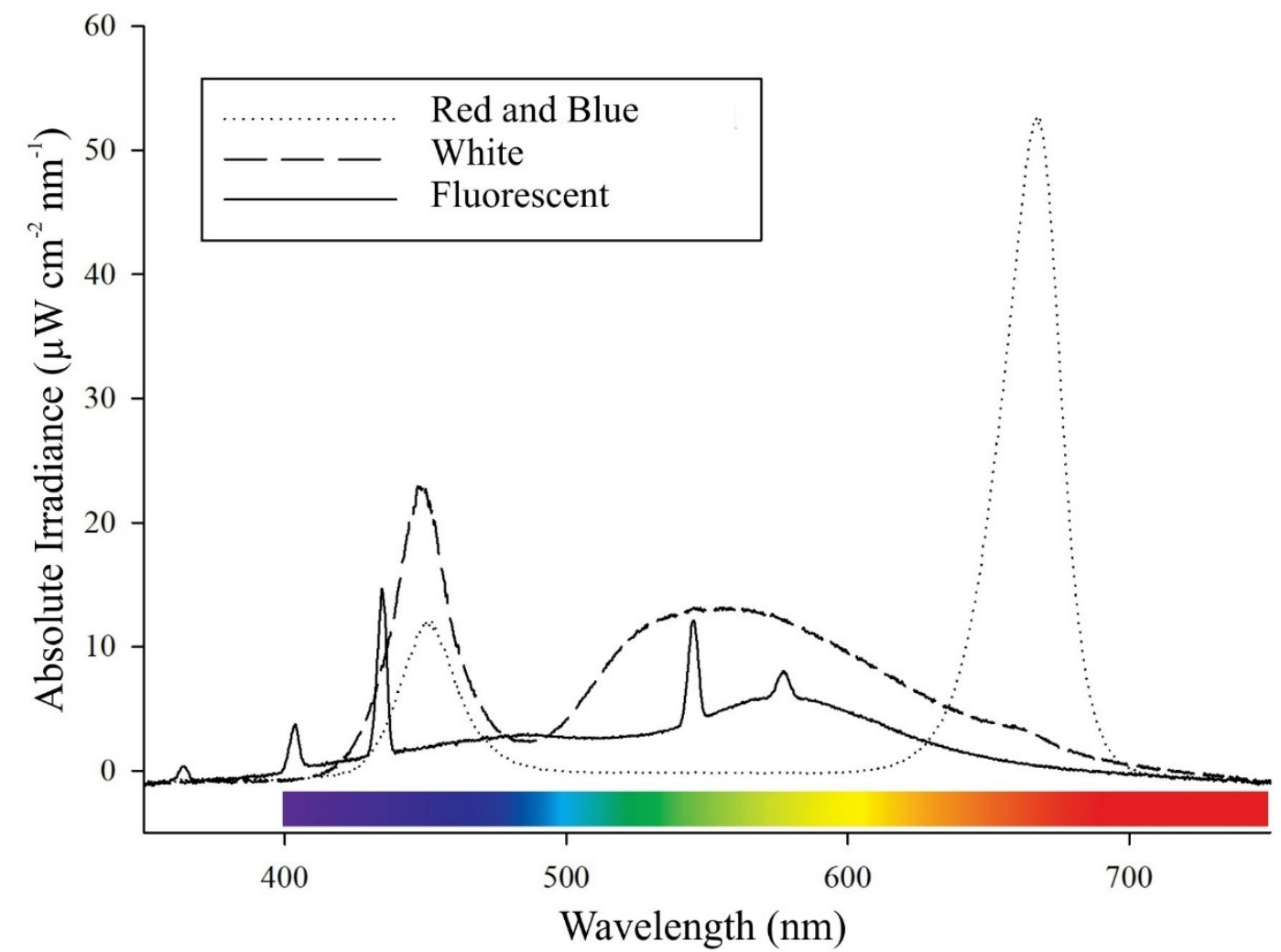

Figure 1. Variations of the absolute irradiance $\left(\mu \mathrm{W} \mathrm{cm}{ }^{-2} \mathrm{~nm}^{-1}\right)$ and the wavelength $(\mathrm{nm})$ of light emitted by fluorescent lamps, white LEDs and red/blue LEDs used in experimentation of explants multiplication in the in vitro condition of hybrid clones of Corymbia, obtained in the growth room.

Shoot length $(>0.5 \mathrm{~cm})$, average number of shoots per explant $(>0.5 \mathrm{~cm})$, oxidation and vigor according to the scale of notes proposed by Oliveira et al. (2016) (Figures 2A and 2B) were evaluated at 30 days of cultivation.

\section{BA growth regulator}

With the results obtained in the light quality experiment, R/B was used for all analyzed clones. The experiment with BA ( 6 - Benzyladenine - Sigma Co) was conducted in a completely randomized design in a $4 \times 4$ factorial arrangement, with four Corymbia hybrid clones: (TC01, TC02, TC03 and CT01) and four concentrations of BA $\left(0,5,1.0,1.5\right.$ and $\left.2.0 \mathrm{mg} \mathrm{L}^{-1}\right)$, with four replications, composed of plots with ten explants.

Shoot length $(>0.5 \mathrm{~cm})$, average number of shoots per explant $(>0.5 \mathrm{~cm})$, oxidation and vigor according to the scale of notes (Figure $2 \mathrm{~A}$ and $2 \mathrm{~B}$ ) were evaluated at 30 days of cultivation. 


\section{Number of subcultures}

The treatments that provided the best results in terms of BA concentrations, for clones TC01, TC02 and TC03, $0.5 \mathrm{mg} \mathrm{L}^{-1}$ and CT01 $1.0 \mathrm{mg} \mathrm{L}^{-1}$ of the growth regulator were used. For the number of subcultures, the experiment was arranged in a completely randomized design in a $4 \times 10$ factorial arrangement, with four Corymbia hybrid clones (TC01, TC02, TC03 and CT01) and ten subcultures, with four replications, composed of plots with ten explants.

Shoot length $(>0.5 \mathrm{~cm})$, average number of shoots per explant $(>0.5 \mathrm{~cm})$, oxidation and vigor according to the scale of notes (Figure 2A and 2B) were evaluated at 30 days of cultivation.

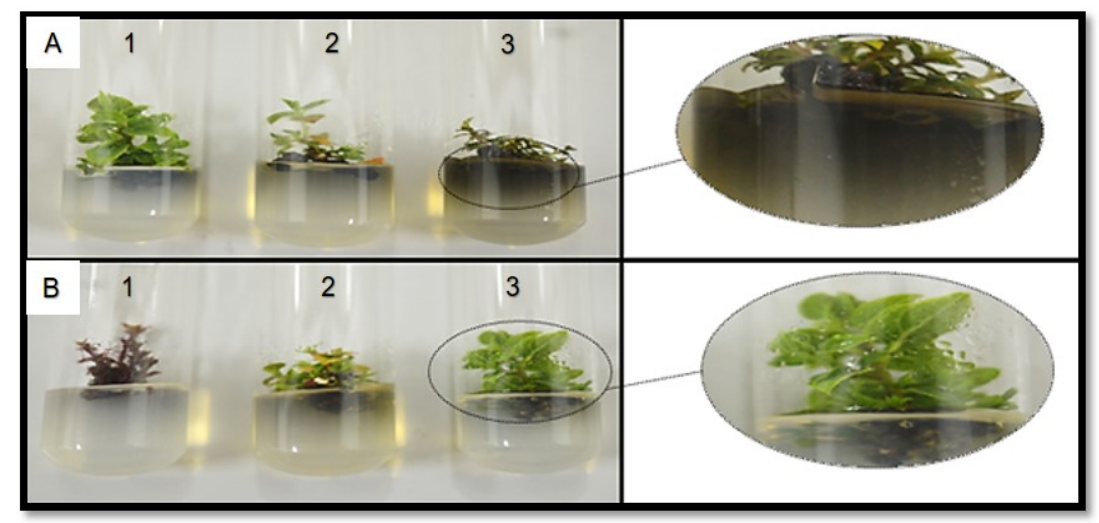

Figure 2. Oxidation and vigor assessments according to a scale of notes. (A) Oxidation of shoots ( 1 = Null: no oxidation; 2 = Average: reduced oxidation at the base of the explants (medium with grayish tonality; $3=$ High: complete oxidation of shoots) (B) Shooting vigor (1 = Low: no induction of shoots and, or, senescence and death; 2 = Good: induction of shoots, but with leaves of reduced size; 3 = Great: induction of shoots with active growth, without apparent nutritional deficiency).

\section{Data analysis}

The analyses were processed using R software, version 3.0.3 (R Core Team, 2014), with the aid of the ExpDes package, version 1.1.2 (Ferreira et al., 2013). Variables that did not show normal distribution according to the Shapiro-Wilk test at $5 \%$ were transformed by arcsen. The treatment means were subjected to analysis of variance (ANOVA), with the Tukey test at 5\% significance and adjustments to the regression equations.

\section{RESULTS AND DISCUSSION}

\section{Effect of light quality on in vitro multiplication}

Under the experimental conditions, for the studied characteristics, a difference was observed in the response between clones, as well as in the light qualities evaluated in the in vitro multiplication of Corymbia hybrid clones.

Regarding the explant shoot length variable at 30 days in the multiplication stage, the highest values were observed for clone CT01 (on average $2.17 \mathrm{~cm}$ ) in the R/B light source. For clone TC01, R/B also provided the highest values for shoot length, differing statistically for the other light qualities ( $p$ $<0.05$ ). In relation to clone TC02 and TC03, the highest averages were observed with the use of W/L light (Figure 3A). There is a very wide variation in the plant's physiological responses to LEDs, which are translated into metabolic and genetic processes that promote changes in growth and development, in order to optimize plant adaptations to changes in environmental conditions (Lazzarini et al., 2017).

In the induction of shoots per explant in the multiplication stage, for the analyzed clones it was observed that the highest average (5.3 shoots) was found in clone TC02 (Figure 3B). In addition, the R/B and W/L light sources induced higher averages in the number of shoots per explant, when compared to F/L (Figure 3B). Due to the specificity in the wavelength, LEDs influence the photomorphogenic 
responses of explants grown in controlled environments, emerging as a useful technology to increase productivity (Batista et al., 2018; Faria et al., 2019).

Data described in the literature corroborate those found in this study, since the combination of R/B LEDs in Populus euramericana Moench (pro sp.) (Kwon et al., 2015), Vaccinium corymbosum L. (Hung et al., 2016), Acer saccharum Marsh. (Singh et al., 2017) and Corymbia citriodora $\times$ C. torelliana (Souza et al., 2018), induced a greater number and growth of shoots.

The values were very close for oxidation and vigor according to a scale of notes among the hybrid clones of Corymbia (Figure $3 \mathrm{C}$ and $3 \mathrm{E}$ ), without significant differences $(p>0.05)$. When R/B and W/L light sources were compared, they did not differ statistically $(p>0.05)$, however R/B showed lower values for oxidation (Figure 3D) and higher W/L for vigor compared to F/L light source $(p<0.05)$ (Figure 3F). These results are close to those found by Souza et al. (2018) who observed low phenolic oxidation and adequate vigor for in vitro multiplication of Corymbia citriodora $\times C$. torelliana explants in R/B and W/L.
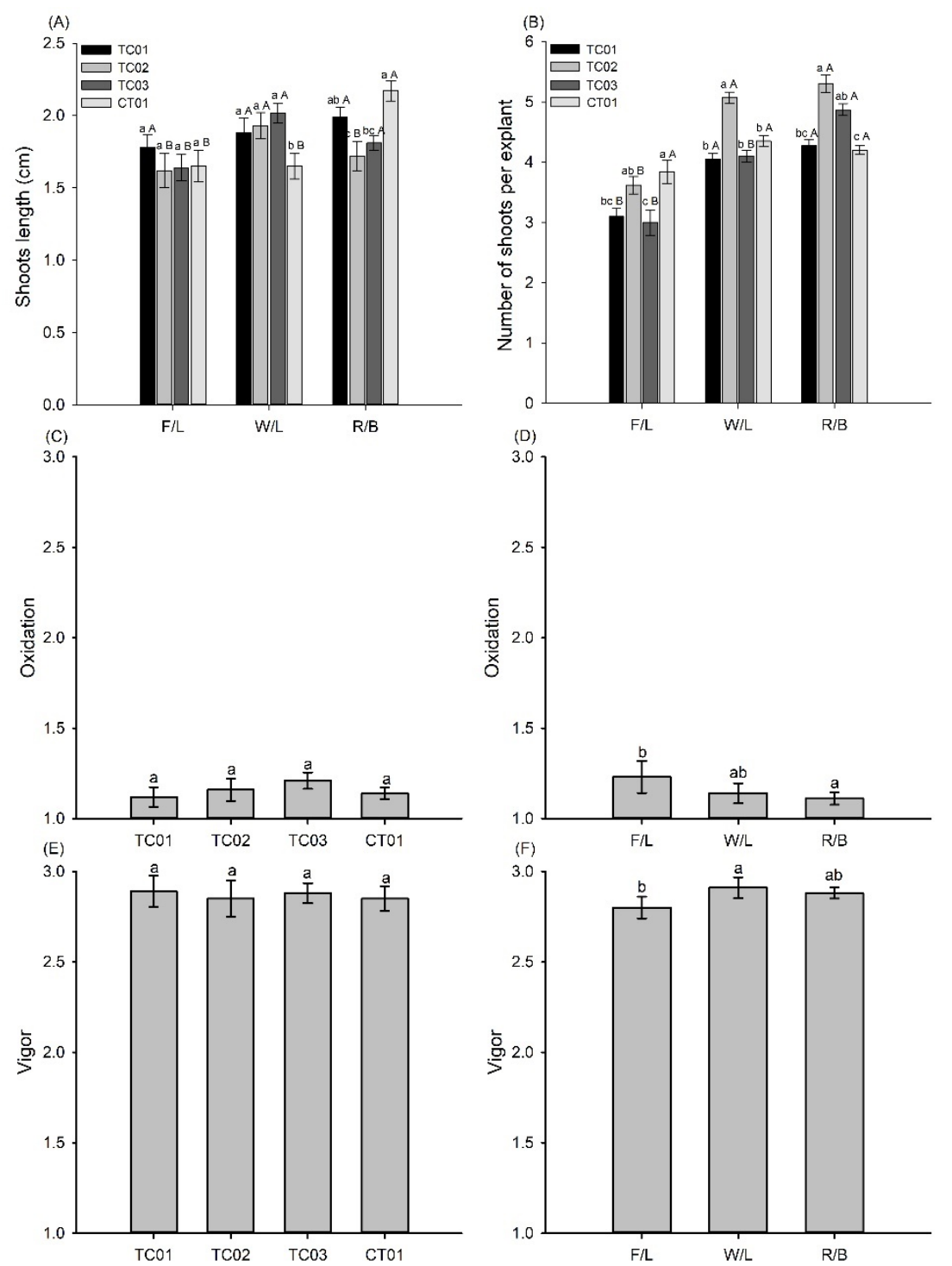

Figure 3. Characteristics observed for in vitro multiplication as a function of the different light quality (F/L, W/L and R/B) and hybrid clones of Corymbia torelliana $\times$ C. citriodora (TC01, TC02 and TC03) and Corymbia citriodora $\times$ C. torelliana (CT01). (A) Shoots length; (B) Number of shoots per explant; (C, D) Oxidation of shoots; (E, F) Shooting vigor. * For (A, B) lowercase letters represent statistical differences by comparing the different clones in the same treatment (light quality) and upper case letters represent statistical differences by comparing the different qualities of light in the same treatment (clone). * Averages followed by the same letter do not differ from each other, by Tukeys test at 5\% probability. 


\section{Effect of BA growth regulator on in vitro multiplication}

When the clones were tested against BA concentrations, it was observed that the TCO2 clone had the highest average for the length of the shoots $(1.85 \mathrm{~cm})$, differing statistically $(p<0.05)$ for the TC03 clone (Figure 4A). As for vigor, clone CT01 promoted the best results (on average 2.89), with a significant difference for clone TC01 (Figure 4E).

In addition, the lower the concentration of $\mathrm{BA}\left(0.5,1.0,1.5\right.$ and $\left.2.0 \mathrm{mg} \mathrm{L}^{-1}\right)$, the greater the length (Figure 4B), vigor (Figure 4F) and the lower shoots oxidation (Figure 4D). Oliveira et al. (2016), working with in vitro multiplication of hybrid clones of Eucalyptus globulus Labill., found that the combination of BA 0.5 $\mathrm{mg} \mathrm{L}^{-1}$ and NAA $0.01 \mathrm{mg} \mathrm{L}^{-1}$ stimulated the growth of shoots, as well as the vegetative vigor of the explants.

When oxidation evaluations were done according to a scale of notes, the lowest averages (1.15) were verified for clone TC01, with significant difference $(p<0.05)$ for the other treatments (Figure 4C). These results may be related to factors of the cultivation environment, such as light quality, air temperature and relative humidity. In addition, by the use of smaller flasks, there is a tendency to have low concentrations of carbon dioxide and high concentrations of ethylene (Xiao et al., 2011).

Regarding the number of shoots per explant for the analyzed clones related to the tested BA concentrations, it was found that the highest averages (5.3; 4.4 and 4.77 shoots) were in CT01, TC01 and TC03 at the concentration of $1 \mathrm{mg} \mathrm{L}^{-1}$ (Figure 4G), respectively. In contrast to the TC02 clone (on average 4.4 shoots); the concentration of $0.5 \mathrm{mg} \mathrm{L}^{-1}$ showed the highest values (Figure 4G).

Similar results to the study were found in the in vitro multiplication of $E$. globulus under different combinations of NAA and BA, in which concentrations close to $1.0 \mathrm{mg} \mathrm{L}^{-1}$ of BA and $0.05 \mathrm{mg} \mathrm{L}^{-1}$ of NAA, were more efficient for shoot induction (Cordeiro et al., 2014). In contrast, Silva et al. (2013), found an increase in the number of shoots in Caesalpinia pyramidalis Tul. without growth regulators, which shows that higher concentrations of this cytokinin were inhibitory in the multiplication phase.

\section{Effect of the number of subcultures on in vitro multiplication}

The shoot length characteristic of the explants observed in in vitro multiplication showed the factors clone and subculture, to have a significant interaction. Regarding oxidation, the number of shoots per explant and vigor of shoots, the factors acted independently.

Clone TC02 stood out with greater shoot length $(2.63 \mathrm{~cm})$ in the third subculture (Figure 5A). The regression curves in view of the correlation between subcultures and clones showed polynomial behavior of second degree. However, the critical points for the length of the shoots varied from the third to the fourth subcultures (Figure 5A). In this context, similar results were found by Oliveira et al. (2016), showing variation on in vitro multiplication over subcultures, for all clones, making it difficult to distinguish a specific stabilization point.

For the number of shoots per explant and vigor according to the scale of notes, the results showed differences compared to the analyzed clones, and the CT01 had the highest averages (4.51 shoots and 2.89), differing statistically from the other treatments $(p<0.05$ ) (Figure 5B and 5F). In addition, a gradual increase from the first to the ninth subcultures was observed for the number of shoots per explant and vigor of shoots (Figure 5C and 5G). For Eucalyptus benthamii Maiden et Cambage, a higher number of shoots was observed in successive subcultures (Polesi, 2015).

The number of shoots per explant and the vigor of the shoots are characteristics that stand out as a tool to assess the efficiency of the in vitro multiplication phase in successive subcultures (Silva et al., 2016). In addition, variations in responses between genotypes have also been observed in the Eucalyptus multiplication stage (Hartmann et al., 2011), demonstrating that this is a factor that exerts great influence on in vitro cultivation.

Regarding the oxidation of explants according to the scale of notes, it was observed that the values were very close for all clones, with no statistical difference $(p>0.05)$ (Figure 5D). As for subcultures, there was a gradual reduction in oxidation from the first to the fourth subculture (Figure $5 \mathrm{E}$ ).

The results differ from those obtained by Borges et al. (2011) working with E. globulus, in which some clones were shown to be recalcitrant during the in vitro multiplication stage, presenting low vigor and necrosis, which limited their cultivation. One of the main limiting factors for the regeneration of explants is the occurrence of phenolic oxidation (Silva et al., 2015; Tormen et al., 2018), therefore, methodologies aimed at overcoming or reducing tissue oxidation are important strategies to be adopted in the propagation system. 

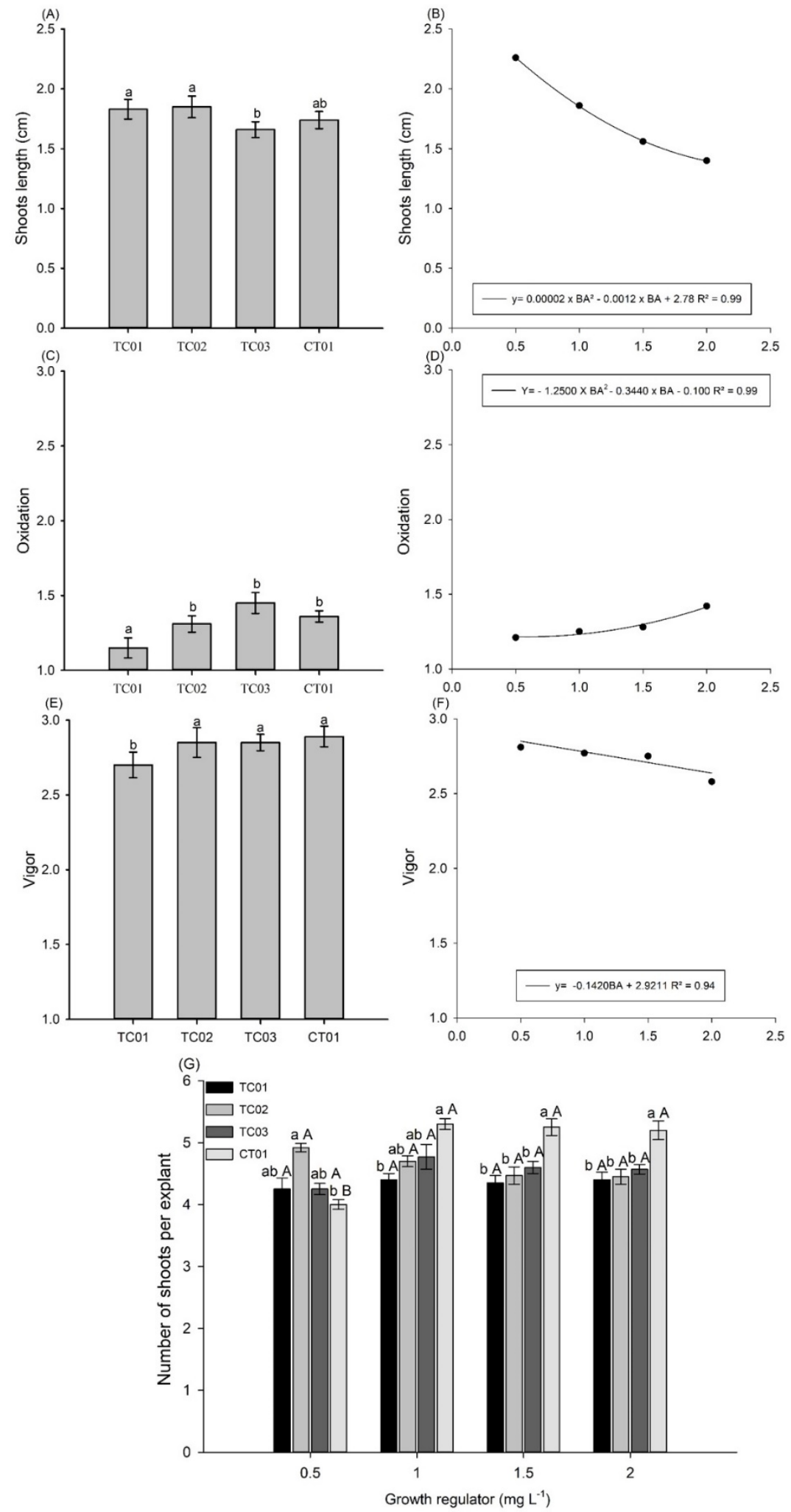

Figure 4. Characteristics observed for in vitro multiplication as a function of the different concentrations of BA $\left(0.5,1.01 .5,2.0 \mathrm{mg} \mathrm{L}^{-1}\right)$ and hybrid clones of Corymbia torelliana $\times$ C. citriodora (TC01, TC02 and TC03) and Corymbia citriodora $\times$ C. torelliana (CT01). (A, B) Shoot length; (C, D) Oxidation of shoots; (E, F) Shooting vigor; (G) Number of shoots per explant. *For (G) lowercase letters represent statistical differences by comparing the different clones in the same treatment (BA) and upper case letters represent statistical differences by comparing the different qualities of light in the same treatment (clone). *Averages followed by the same letter do not differ from each other, by Tukey's test at $5 \%$ probability. 


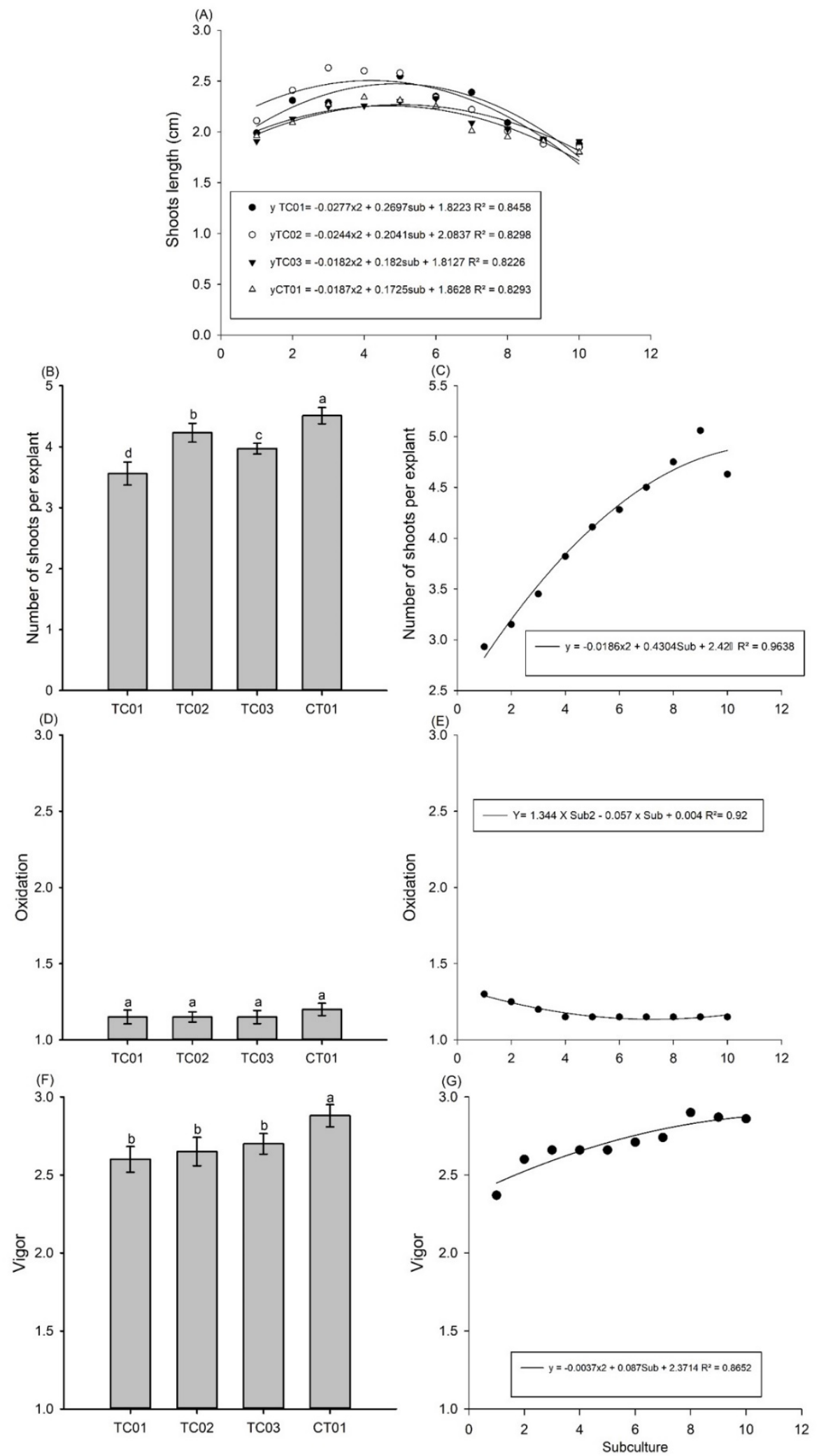

Figure 5. Characteristics observed for in vitro multiplication as a function of subcultures and hybrid clones of Corymbia torelliana $\times$ C. citriodora (TC01, TC02 and TC03) and Corymbia citriodora $\times$ C. torelliana (CT01). (A) Shoot length; (B, C) Number of shoots per explant; (D, E) Oxidation of shoots; (F, G) Shooting vigor. *Averages followed by the same letter do not differ from each other, by Tukey's test at 5\% probability. 


\section{CONCLUSIONS}

Based on the results obtained in the in vitro multiplication stage for the hybrid clones $C$. torelliana $\times$ C. citriodora (TC01, TC02, TC03) and C. citriodora $\times$ C. torelliana (CT01), it can be concluded that: 1) The use of red/blue LEDs was better for all clones analyzed in in vitro multiplication; 2) The explants showed an efficient response to the growth regulator BA stimulus, with the concentration of $0.5 \mathrm{mg} \mathrm{L}^{-1}$ being the one that gave the best result for clones TC01, TC02 and TC03 and $1.0 \mathrm{mg} \mathrm{L}^{-1}$ for clone CT01, promoting greater development of shoots; 3) As for the number of subcultures, the best results for the analyzed clones were obtained in the ninth subculture, with greater proliferation of shoots and vigor of the explants.

\section{ACKNOWLEDGEMENTS}

CNPq (National Council for Scientific and Technological Development, Brazil), FAPEMIG (Minas Gerais State Research Support Foundation) and CAPES (Coordination for the Improvement of Higher Education Personnel) for financial support. BIOAGRO (Institute of Biotechnology Applied to Agriculture) for supplying the laboratory with infrastructure. CMPC (Celulose Riograndense) for genetic material.

\section{REFERENCES}

Assis, T. F. (2014). Melhoramento genético de Eucalyptus: desafios e perspectivas. In Anais do $3^{\circ}$ Encontro Brasileiro de Silvicultura (pp. 127-148). Jataí: UFJ.

Batista, D. S., Felipe, S. H. S., Silva, T. D., de Castro, K. M., Mamedes-Rodrigues, T. C., Miranda, N. A., RíosRíos, A. M., Faria, D. V., Fortini, E. A., Chagas, K., Torres-Silva, G., Xavier, A., Arencibia, A. D., \& Otoni, W. C. (2018). Light quality in planttissueculture: does it matter? In Vitro Cellular \& Developmental Biology - Plant, 54(3), 195-215.

Borges, S. R., Xavier, A., Oliveira, L. S., Melo, L. A., \& Rosado, A. M. (2011). Enraizamento de miniestacas de clones híbridos de Eucalyptus globulus. Revista Árvore, 35, 425-434.

Brondani, G. E., Oliveira, L. S., Konzen, E. R., Silva, A. L. L. D., \& Costa, J. L.. (2018). Mini-incubators improve the adventitious rooting performance of Corymbia and Eucalyptus microcuttings according to the environment in which they are conditioned. Anais da Academia Brasileira de Ciências, 90(2, Suppl. 1), 2409-2423. PMid:29044323.

Cordeiro, G. M., Brondani, G. E., Oliveira, L. S., \& Almeida, M. (2014). Meio de cultura, BAP e ANA na multiplicação in vitro de clones de Eucalyptus globulus Labill. Scientia Forestalis, 42, 337-344.

Correia, D., Gonçalves, A. N., \& do Couto, H. Z., \& Ribeiro, M. C. (1995). Efeito do meio de cultura líquido e sólido no desenvolvimento de gemas de Eucalyptus grandis $\times$ Eucalyptus urophylla na multiplicação in vitro. IPEF, 48-49, 107-116.

El-Showk, S., Ruonala, R., \& Helariutta, Y. (2013). Crossing paths: cytokinin signalling and crosstalk. Development, 140(7), 1373-1383. PMid:23482484.

Faria, D. V., Correia, L. N. F., Souza, M. V. C., Ríos-Ríos, A. M., Vital, C. E., Batista, D. S., Costa, M. G. C., \& Otoni, W. C. (2019). Irradiance and light quality affect two annatto (Bixaorellana L.) cultivars with contrasting bixin production. Journal of Photochemistry and Photobiology. B, Biology, 197, 111549. PMid:31302348.

Ferreira, E. B., Cavalcanti, P. P., \& Nogueira, D. A. (2013). ExpDes: Experimental Designs package. R package version 1.1.2. Vienna: R Foundation for Statistical Computing.

Gupta, S. D., \& Jatothu, B. (2013). Fundamentals and applications of light emitting diodes (LEDs) in in vitro plant growth and morphogenesis. Plant Biotechnology Reports, 7, 211-220.

Hartmann, H. T., Kester, D. E., Davies Junior, F. T., \& Geneve, R. L. (2011). Plant propagation: principles and practices (8th ed., 900 p). New Jersey: Englewood Clipps.

Hsie, B. S., Bueno, A. I. S., Bertolucci, S. K. V., Carvalho, A. A., Cunha, S. H. B., Martins, E. R., \& Pinto, J. E. B. (2019). Study of the influence of wavelengths and intensities of LEDs on the growth, photosynthetic pigment, and volatile compounds production of Lippiarotundifolia Cham in vitro. Journal of Photochemistry and Photobiology. B, Biology, 198, 111577. PMid:31376573.

Hung, C. D., Hong, C. K., Kim, S. K., Lee, K. H., \& Park, J. Y. (2016). LED light for in vitro and ex vitro efficient growth of economically important highbush blueberry (Vaccinium corymbosum L.). Acta Physiologiae Plantarum, 38, 1-9. 
Kwon, A. R., Cui, H. Y., Lee, H., Shin, H., Kang, K. S., \& Park, S. Y. (2015). Light quality affects shoot regeneration, cell division, and wood formation in elite clones of Populuseuramericana. Acta Physiologiae Plantarum, 37, 65-74.

Lazzarini, L. E. S., Pacheco, F. V., Silva, S. T., Coelho, A. D., Medeiros, A. P. R., Bertolucci, S. K. V., Pinto, J. E. B. P., \& Soares, J. D. R. (2017). Uso de diodos emissores de luz (led) na fisiologia de plantas cultivadas - revisão. Scientia Agrária Paranaensis, 16, 137-144.

Martínez-Estrada, E., Caamal-Velázquez, J. H., Josafhat Salinas-Ruíz, J., \& Jericó Jabín Bello-Bello, J. J. (2017). Assessment of somaclonal variation during sugarcane micropropagation in temporary immersion bioreactors by intersimple sequence repeat (ISSR) markers. In Vitro Cellular \& Developmental Biology. Plant, 53, 553-560.

Oliveira, L. S., Xavier, A., Lopes, A. P., Takahashi, E. K., \& Otoni, W. C. (2016). Multiplicação e alongamento in vitrode clones híbridos de Eucalyptus globulus. Ciência Florestal, 26(1), 235-247.

Polesi, N. P. E. (2015). Estudo da comunidade bacteriana endofítica e de sua manifestação na micropropagação de Eucalyptus benthamii (Tese de doutorado). Universidade de São Paulo, São Paulo.

R Core Team. (2014). R: A language and environment for statistical computing. Vienna, Austria: R Foundation for Statistical Computing.

Silva, A. L. L., Brondani, G. E., Olveira, L. S., Gollo, A. L., Horbach, M. A., Machado, M. P., \& Costa, J. (2015). Micropropagation of Eucalyptus saligna Sm. from cotyledonary nodes. Pakistan Journal of Botany, 47, 311-318.

Silva, I. M. C., Winkelmann, M. C., Braga, E. J. B., Peters, J. A., Cuchiara, C., Bianchi, J. V., \& Dutra, L. F. (2016). In vitro multiplication of pear tree cultivar Cascatense. Ciências Agrárias, 37, 581-594.

Silva, T. S., Nepomuceno, C. F., Borges, B. P. S., Alvim, B. F. M., \& Santana, J. R. F. (2013). In vitro multiplication of Caesalpinia pyramidalis (Leguminosae). Sitientibus. Série Ciências Biológicas, 13, 1-6.

Singh, A. S., Jones, A. M. P., Shukla, M. R., \& Saxena, P. K. (2017). High light intensity stress as the limiting factor in micropropagation of sugar maple (Acer saccharum marsh.). Plant Cell, Tissue and Organ Culture, 129, 209-221.

Souza, D. M. S. C., Xavier, A., Otoni, W. C., Miranda, N. A., \& Maggioni, J. H. (2018). Light quality in the in vitro introduction of Corymbia hybrid clones. Revista Árvore, 42(6), 1-9.

Tormen, G. C. R., Figueiredo, A. J. R., Ribeiro, A. S., Santos, L. F., Araújo, J. F., Brondani, G. E., \& Silva, A. L. L. (2018). Carbohydrate sources, alanine and calcium for in vitro multiplication of Eucalyptus cloeziana F. Muell. Ilheringia, 73, 329-335.

Trueman, S. J., Hung, C. D., \& Wendling, I. (2018). Tissue culture of Corymbia and Eucalyptus. Forests, 9(2), $1-42$.

Xiao, Y., Niu, G., \& Kozai, T. (2011). Development and application of photoautotrophic micropropagation plant system. Plant Cell, Tissue and Organ Culture, 105, 149-158.

Authors' contributions: DMSCS: conceptualization, data curation, formal analysis, methodology, writing - original draft, writing - review \& editing; AX: supervision, validation, visualization; NAM: conceptualization, data curation, formal analysis, methodology, writing - original draft, writing - review \& editing; RG: formal analysis, methodology, writing - original draft; WCO: supervision, validation, visualization. 